\title{
APPLICATION OF PLURONIC F68 FOR AQUEOUS TWO-PHASE EXTRACTION OF PROTEINS
}

\author{
TOSHIHIKO KITAHARA, MASAMICHI KAMIHIRAAND \\ HIROSHI TAKEUCHI* \\ Department of Chemical Engineering, Faculty of Engineering, \\ Nagoya University, Chikusa-ku, Nagoya 464-01
}

Key Words: Biochemical Engineering, Aqueous Two-Phase Extraction, Bioseparation, Pluronic F68, Binodial Curve, Monoclonal Antibody

\begin{abstract}
Studies were made of the application of a block copolymer of polyethylene oxide and polypropylene oxide, Pluronic F68, to aqueous two-phase extraction of proteins. For Pluronic F68/salt systems, the effects of temperature, salt concentration and $\mathrm{pH}$ on the binodials and protein partitioning were studied. Pluronic F68/ salt system had a region in which Pluronic F68 becomes solid in phase diagram at $25^{\circ} \mathrm{C}$. Partitioning of the proteins between the two phases could be controlled by varying salt composition. Further applicability of the Pluronic F68/ammonium sulfate system was examined for the purification of monoclonal antibodies from various hybridoma culture broths. Aqueous two-phase extraction provided a simple and rapid separation and concentration method with high recovery.
\end{abstract}

\section{Introduction}

Liquid-liquid extraction is a traditional unit operation in chemical engineering. It affords easy scale-up, and many types of apparatus have been developed. In the field of bioseparation, however, the application of liquid-liquid extraction has been limited in the antibiotics industry, since it is difficult to extract biomaterials such as proteins in normal organic solvents. Aqueous polymer two-phase systems, in which both phases usually contain more than $70 \%$ water provide a gentle operation favorable to the separation of various biological substances such as proteins and organelles ${ }^{1,16)}$. Aqueous two-phase systems are formed when two polymers, e.g., polyethylene glycol (PEG) and dextran, are mixed at an appropriate concentration in water. Then the solvated polymers cause a phase separation: the PEG-rich upper phase and the dextran-rich bottom phase. The two phases are different from each other in physical and chemical environments, which allows for selective partitioning of solutes. The partition coefficient of a protein between the two phases depends on physicochemical variables such as hydrophobicity, molecular size and electrochemical property, as well as environmental conditions such as $\mathrm{pH}$, ionic strength, temperature and protein concentration. Extensive studies of protein partitioning have also been made using PEG/dextran and PEG/salt two-phase systems ${ }^{1,16)}$.

In recent years, Pluronic F68, a block copolymer of polyethylene oxide and polypropylene oxide, has attracted attention as a protecting agent against mechanical damage during agitation and bubbling in animal cell culture $^{4,8,12)}$ and for stimulating growth of animal

\footnotetext{
* Received October 2, 1992. Correspondence concerning this article should be addressed to $\mathrm{H}$. Takeuchi.
}

cells $^{3,14)}$. Although animal cells are shear-sensitive, the use of Pluronic F68 made it possible to supply oxygen efficiently by direct bubbling aeration. Monoclonal antibodies, one of the most important bioproducts in animal cell culture, have also been produced effectively by hybridoma culture containing Pluronic $\mathrm{F} 68^{15}$. If the polymer can be used as a phase-forming polymer for aqueous two-phase extraction of monoclonal antibodies, then it provides great potential in both production and recovery of monoclonal antibodies.

In the present study, the conventional polymers in an aqueous two-phase system were replaced by Pluronic F68 and various salts. The binodials in Pluronic F68/ salts systems and its applicability to protein extraction were examined. In addition, the Pluronic F68/ammonium sulfate system was applied to the separation of mouse-IgG and human-IgM monoclonal antibodies from both serum-free and serum-containing media as the hybridoma culture broth.

\section{Experimental}

\subsection{Materials}

Pluronic F68 (average molecular weight, MW = 8,500 ) was kindly provided by BASF Japan Co., Osaka. PEG4000 (MW = 3,000) and PEG6000 (MW = 8,500) were purchased from Tokyo Kasei Kogyo Co., Tokyo. Yeast alcohol dehydrogenase (ADH; MW $=145,000, \mathrm{pI}$ $=5.4$ ) and bovine serum albumin (BSA; $\mathrm{MW}=67,500$, $\mathrm{pI}=4.7$ ) were obtained from Sigma Chemical Co., $\mathrm{MO}$, USA. Bovine hemoglobin ( $\mathrm{MW}=68,000, \mathrm{pI}=6.8)$ and egg white lysozyme $(\mathrm{MW}=13,900, \mathrm{pI}=11)$ were from Wako Pure Chemical Co., Osaka and Seikagaku Kogyo 


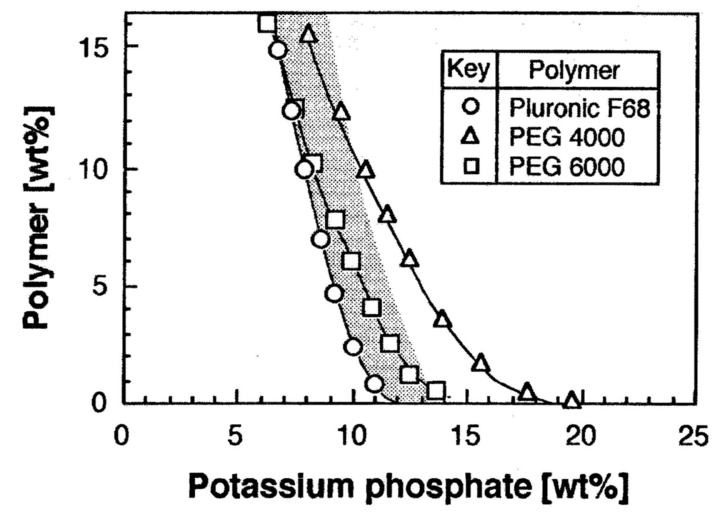

Fig. 1 Binodial curves of Pluronic F68, PEG4000, and PEG6000/potassium phosphate systems at $25^{\circ} \mathrm{C}$

Co., Tokyo respectively. Other chemicals were of guaranteed grade.

\subsection{Measurement of binodial curve}

Phase diagrams (binodial curves) were determined by the turbidity method described by Albertsson ${ }^{1)}$. About one gram of $30 \mathrm{wt} \%$ PEG solution was put into a test tube. Then, $30 \mathrm{wt} \%$ salt solution was added dropwise to the tube and was mixed thoroughly. When turbidity appeared in the mixture and a two-phase system arose, the composition of the mixture was determined. Additional points were obtained by adding a small amount of water to clear the system and then the salt solution to produce turbidity again. Thus, a series of compositions, close to the binodial, were obtained. For the two-phase systems containing a secondary salt, predetermined concentrations of the salt were added to each solution for obtaining the binodials.

\subsection{Protein partitioning}

Predetermined amounts of Pluronic F68, salts and water were mixed, and then protein solution was added to the mixture. The $\mathrm{pH}$ value of the system was adjusted by changing the ratio of $\mathrm{KH}_{2} \mathrm{PO}_{4}$ and $\mathrm{K}_{2} \mathrm{HPO}_{4}$. For $\mathrm{pH}$ higher than 10, a small amount of $\mathrm{NaOH}$ was added to the system. After vigorous shaking for $10 \mathrm{~min}$, the mixture was allowed to stand for $24 \mathrm{~h}$ in a thermostated water bath. After two phases were separated by centrifugation, the volume of the top and bottom phases was measured. Each phase was collected and diluted with water. The protein concentration was determined from absorbance at $280 \mathrm{~nm}$ and/or a dye-binding method (a protein assay kit from Bio-Rad Laboratories Co., CA, USA).

1.4 Separation and recovery of monoclonal antibodies from hybridoma culture broth

A mouse-mouse hybridoma, $16-3 \mathrm{~F}^{7}$, which produces anti-thermostable $\alpha$-amylase IgG-type monoclonal antibody, was cultured in DF-ITES serum-free medium ${ }^{7)}$ or RDF medium supplemented $5 \%$ fetal calf serum. The cells were inoculated to fresh medium at a concentration of $5 \times 10^{5}$ cells $/ \mathrm{cm}^{3}$. The broths were replaced by each fresh medium every two days, and the spent media were used for separation of the antibody after eliminating the cells by centrifugation. The concentration of the antibody

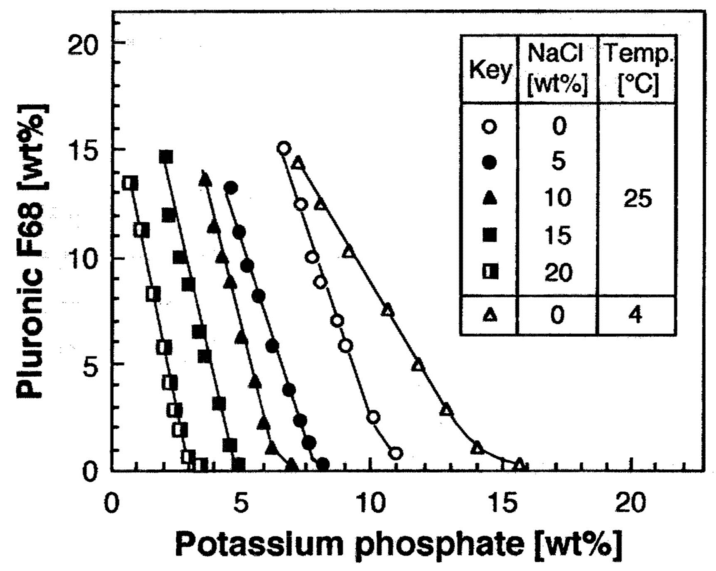

Fig. 2 Effect of $\mathrm{NaCl}$ concentration and temperature on binodial curve of Pluronic F68/potassium phosphate system

was $43 \mu \mathrm{g} / \mathrm{cm}^{3}$ and $97 \mu \mathrm{g} / \mathrm{cm}^{3}$ for DF-ITES medium and RDF medium respectively. Human IgM-type monoclonal antibody was harvested in the same manner as that from the culture broth of a human-human hybridoma, SI-102, by use of ERDF-ITES-Ylp serum-free medium $^{13)}$. The IgM was obtained at a concentration of $55 \mu \mathrm{g} / \mathrm{cm}^{3}$.

Pluronic F68 (1.0 wt\%), $\left(\mathrm{NH}_{4}\right)_{2} \mathrm{SO}_{4}(15.0 \mathrm{wt} \%$, $19.5 \mathrm{wt} \%$ or $23.8 \mathrm{wt} \%)$ and $\mathrm{NaSCN}(0 \mathrm{wt} \%, 5 \mathrm{wt} \%$ or 10 wt $\%)$ were added to the broth $\left(9-10 \mathrm{~cm}^{3}\right)$ to make aqueous two-phase in an ice-bath. Both phases were separated, and each phase was applied to dialysis against phosphate-buffered saline solution (PBS; $\mathrm{pH} 7.4,0.14 \mathrm{M}$ $\mathrm{NaCl})$ after dilution with water. The operation was performed at $4^{\circ} \mathrm{C}$, then the concentrations of the antibodies and proteins in the dialyzates were analyzed.

\subsection{Analyses}

The concentration of Pluronic F68 was determined by a colorimetric assay according to Hasko et $a l^{6}{ }^{6}$. The concentrations of phosphate and sulfate were measured by the molybdenum blue method ${ }^{2)}$ and by the barium sulfate turbidimetric method ${ }^{9)}$ respectively.

Antibody concentration was determined by a solidphase enzyme-linked immunosorbent assay (ELISA). The wells of a microtiter plate (Becton Dickinson Co., MA, USA) were coated overnight at $4^{\circ} \mathrm{C}$ with IgG fraction of sheep anti-mouse IgG or anti-human IgM serum (Organon Teknika Co., PA, USA). The plate was washed three times with PBS containing $0.05 \%$ Tween 20 (Tween-PBS). Subsequently, the samples were poured into the wells, and the plate was allowed to stand for 30 min. After washing three times with Tween-PBS again, the diluted solution of goat anti-mouse IgG or antihuman IgM conjugated to horseradish peroxidase (Organon Teknika Co.) was poured into the wells and the plate stood for $1 \mathrm{~h}$. Finally, the wells were washed four times with Tween-PBS, and then the immobilized enzyme was detected by adding substrate solution containing $\mathrm{H}_{2} \mathrm{O}_{2}$ and $o$-phenylenediamine. The antibody concentration was determined by spectrophotometry at $490 \mathrm{~nm}$ on a microplate reader (Model 450; Bio-Rad 


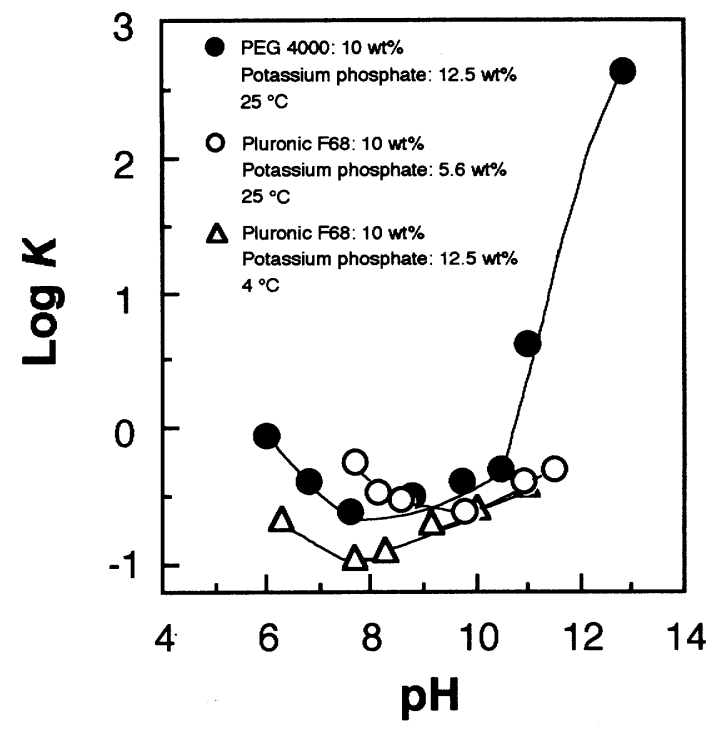

Fig. 3 Effect of pH on partitioning of lysozyme in Pluronic F68 and PEG4000/potassium phosphate systems

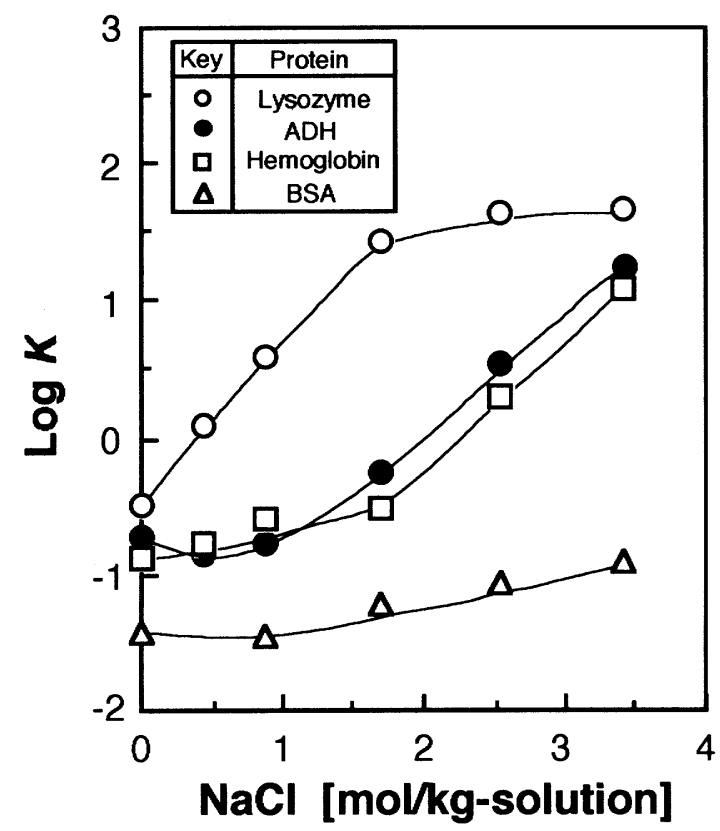

Fig. 4 Effect of $\mathrm{NaCl}$ addition on protein partitioning in Pluronic F68/potassium phosphate system at $25^{\circ} \mathrm{C}$

Laboratories Japan Co., Tokyo) using purified mouseIgG or human-IgM (Organon Teknika Co.) as a standard antibody.

\section{Results and Discussion}

\subsection{Binodials in Pluronic F68/salt aqueous two- phase systems}

Figure 1 shows a typical binodial curve obtained for Pluronic F68/potassium phosphate system at $25^{\circ} \mathrm{C}$, together with the results for the two-phase systems of PEG4000/potassium phosphate and PEG6000/potassium phosphate. It indicates that the phase separation in the Pluronic F68 system takes place at lower polymer concentration than in the PEG systems. Pluronic F68 is of

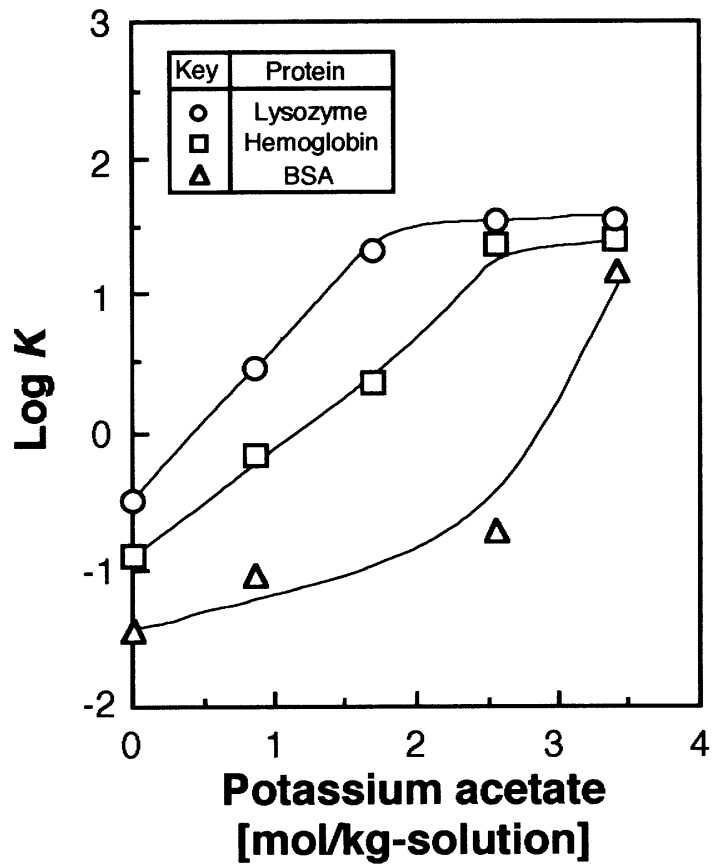

Fig. 5 Effect of potassium acetate addition on protein partitioning in Pluronic F68/potassium phosphate system at $25^{\circ} \mathrm{C}$

almost the same molecular weight as PEG6000; however, the former is more hydrophobic than the latter, owing to the polypropylene oxide portion. Thus, the binodial of the Pluronic F68 system had a strong dependence on phosphate concentration, whereas the difference in the phase separation behavior between the two PEG systems can be attributed to the difference in molecular weight. In addition, an increase in phosphate or Pluronic F68 led to solidification of the polymer. Such behavior was also observed in other Pluronic F68/salt systems such as Pluronic $\mathrm{F} 68 /\left(\mathrm{NH}_{4}\right)_{2} \mathrm{SO}_{4}$ (data not shown), when the operation was performed at $25^{\circ} \mathrm{C}$. Therefore, the operating region for forming the aqueous two-phase system ranges over the shadow portion in Fig. 1.

Figure 2 shows the effects of addition of $\mathrm{NaCl}$ and temperature on the binodial for the present system. With decreasing temperature the binodials shifted to the right region without solidification of the polymer. On the other hand, the addition of $\mathrm{NaCl}$ allowed the binodial to shift to the left side with the same dependence of phosphate concentration in sequence of the salt concentration.

The solidification is characteristic of Pluronic F68/ salt systems, and it can be controlled by changing composition and/or temperature; thus the recovery of Pluronic F68 from the spent solution might be feasible in the practical application. Harris et al. reported similar behavior of temperature-dependent solidification for random copolymer of ethylene oxide and propylene oxide/dextran or hydroxypropyl starch systems ${ }^{5)}$.

\subsection{Protein partitioning}

Effect of $\mathrm{pH} \quad$ Figure 3 shows the effect of $\mathrm{pH}$ on the 
Table 1. Purification of mouse-IgG monoclonal antibody from hybridoma culture broth using DF-ITES serum-free medium

\begin{tabular}{|c|c|c|c|c|c|c|c|c|c|}
\hline & & $\begin{array}{c}\left(\mathrm{NH}_{4}\right)_{2} \mathrm{SO}_{4} \\
{[\mathrm{wt} \%]}\end{array}$ & $\begin{array}{l}\text { Volume ratio } \\
\text { [top/bottom] }\end{array}$ & $\begin{array}{c}\text { Total } \\
\text { protein }^{\mathrm{b})} \\
{[\mu \mathrm{g}-\text { protein }} \\
\left./ \mathrm{cm}^{3}\right]\end{array}$ & $\begin{array}{c}\text { Total } \\
\text { activity } \\
\text { [ } \mu \text { g-antibody } \\
\left./ \mathrm{cm}^{3}\right]\end{array}$ & $\begin{array}{c}\text { Specific } \\
\text { activityb) }^{\mathrm{b}} \\
\text { [g-antibody } \\
\text { /g-protein] }\end{array}$ & $K[-]$ & $\begin{array}{c}\text { Purification } \\
\text { factor }^{\text {b) }} \\
{[-]}\end{array}$ & $\begin{array}{c}\text { Recovery }{ }^{\text {b) }} \\
{[\%]}\end{array}$ \\
\hline & Crude & - & - & 103 & 43 & 0.42 & - & 1.0 & 100 \\
\hline & $\begin{array}{l}\text { Aqueous two-phase } \\
\text { extraction }^{\text {a) }}\end{array}$ & $\begin{array}{l}15.0 \\
19.5 \\
23.8\end{array}$ & $\begin{array}{l}0.057 \\
0.055 \\
0.054\end{array}$ & $\begin{array}{r}89 \\
528 \\
781\end{array}$ & $\begin{array}{r}46 \\
234 \\
581\end{array}$ & $\begin{array}{l}0.51 \\
0.44 \\
0.74\end{array}$ & $\begin{array}{r}1.5 \\
9.7 \\
90.2\end{array}$ & $\begin{array}{l}1.2 \\
1.1 \\
1.8\end{array}$ & $\begin{array}{l}13 \\
34 \\
85\end{array}$ \\
\hline i) & $\begin{array}{l}\text { Pluronic F68: } 1 \mathrm{wt} \% \text {. } \\
\text { The data are on the to }\end{array}$ & phase. & & & & & & & \\
\hline
\end{tabular}

Table 2. Purification of human-IgM monoclonal antibody from hybridoma culture broth using ERDF-ITES-Ylp serum-free medium

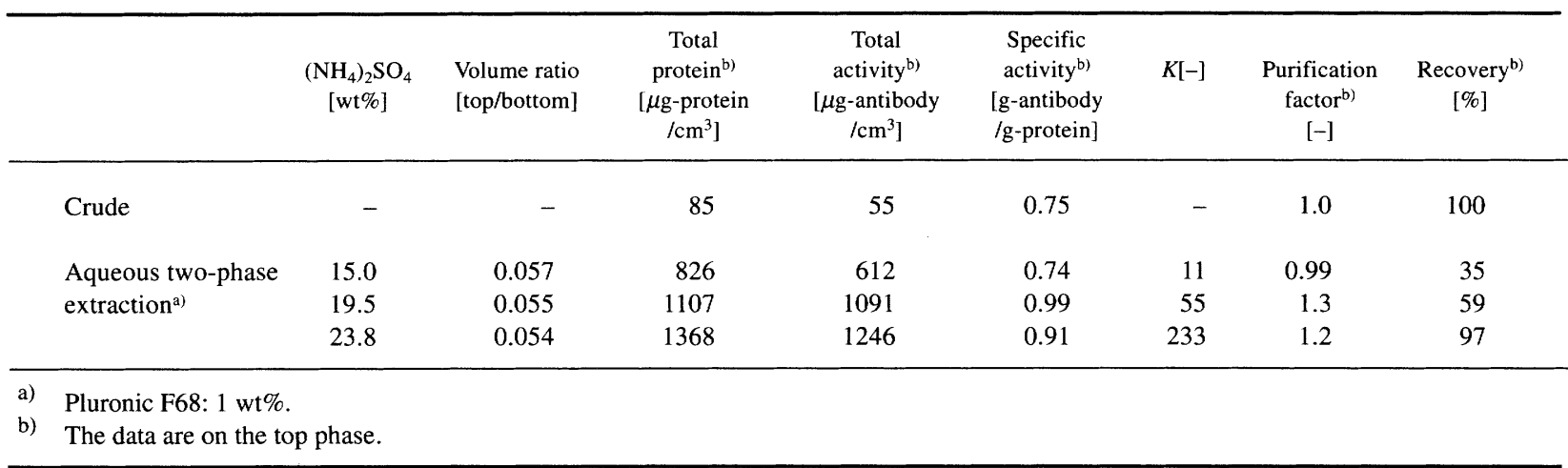

partition coefficient, $K=$ (protein concentration in the top phase)/(protein concentration in the bottom phase), of lysozyme in the two-phase systems of Pluronic F68/ potassium phosphate and of PEG4000/potassium phosphate. For the pH below its $\mathrm{pI}$, the same trend of the $K$ values was observed between the two-phase systems. It seems that the partitioning of the protein was dominated by the difference in the hydrophobicity of both phases with variation of $\mathrm{pH}^{10)}$. For the $\mathrm{pH}$ above its $\mathrm{pI}$, however, a drastic increase in the $K$ value was caused by an electrostatic interaction for the PEG/phosphate system; i.e. lysozyme is liable to be partitioned in the upper phase from the electrostatic repulsion between the negative charge of the protein and the phosphate ion in the lower phase. However, no drastic increase in the $K$ value appeared in the Pluronic F68/phosphate system, since the polymer solidified at $\mathrm{pH}$ higher than 11.5 . Such $\mathrm{pH}$ effect was also observed in the partitioning of ADH.

Effect of additives as secondary salt As seen in Fig. 2, the addition of $\mathrm{NaCl}$ in the Pluronic F68/potassium phosphate system had a significant effect on the phase separation. Figure 4 shows a plot of $\log K$ against $\mathrm{NaCl}$ concentration as a secondary salt for the partitioning of four proteins. In all experimental runs the polymer concentrations were $10 \mathrm{wt} \%$, and the phosphate concentration was adjusted so as to have a constant concentration of the polymer in each upper phase. The $\mathrm{pH}$ value in the systems was 6.8-7.0. The $K$ values thus obtained increased with the concentration of $\mathrm{NaCl}$ for all proteins used in this system. This may be due to a rise in the hydrophobicity of the proteins, caused by the salting-out effect $^{11}$.

Figure 5 shows the results for the addition of potassium acetate under the same conditions as in Fig. 4. The acetate also had a significant effect on the protein partitioning, and its contribution for both the proteins of BSA and hemoglobin was greater than that of $\mathrm{NaCl}$. It should be noted that this sequence corresponds to the Hofmeister series of anions added as a secondary salt.

From these results, a conclusion can be drawn that the addition of secondary salt is significant for partitioning of proteins to the top phase in Pluronic F68/salt systems, and that the mechanism of partitioning is mainly due to increase in hydrophobicity of proteins from the salting-out effect.

\subsection{Application of Pluronic F68/ammonium sulfate system to separation of monoclonal antibodies from hybridoma culture broths}

To examine the applicability of Pluronic F68/salt two-phase systems to practical protein separation, we attempted to separate mouse-IgG and human-IgM monoclonal antibodies from the supernatant of hybridoma culture broths. In this experiment, $\left(\mathrm{NH}_{4}\right)_{2} \mathrm{SO}_{4}$ was used as a phase-forming salt, because it is most popular for salting-out of protein. Although the phase diagram of the system was different from that of the Pluronic F68/ potassium phosphate system, the trend of protein partitioning was similar in the two systems (data not shown). 
Table 3. Purification of mouse-IgG monoclonal antibody from hybridoma culture broth using DF-ITES medium supplemented with $0.5 \%$ BSA

\begin{tabular}{|c|c|c|c|c|c|c|c|c|c|}
\hline & & $\begin{array}{c}\mathrm{NaSCN} \\
{[\mathrm{wt} \%]}\end{array}$ & $\begin{array}{l}\text { Volume ratio } \\
\text { [top/bottom] }\end{array}$ & $\begin{array}{c}\text { Total } \\
\text { protein }{ }^{\mathrm{b})} \\
{[\mu \mathrm{g} \text {-protein }} \\
\left./ \mathrm{cm}^{3}\right]\end{array}$ & $\begin{array}{c}\text { Total } \\
\text { activity } \\
{[\mu \mathrm{g} \text {-antibody }} \\
\left./ \mathrm{cm}^{3}\right]\end{array}$ & $\begin{array}{c}\text { Specific } \\
\text { activity } \\
\text { [g-antibody } \\
\text { /g-protein] }\end{array}$ & $K[-]$ & $\begin{array}{c}\text { Purification } \\
\text { factor }^{\text {b) }} \\
{[-]}\end{array}$ & $\begin{array}{c}\text { Recoveryb) } \\
{[\%]}\end{array}$ \\
\hline & Crude & - & - & 6243 & 35 & 0.0056 & - & 1.0 & 100 \\
\hline & \multirow{3}{*}{$\begin{array}{l}\text { Aqueous two-phase } \\
\text { extraction }^{\text {a) }}\end{array}$} & 0 & 0.054 & 6156 & 745 & 0.12 & 113 & 21 & 98 \\
\hline & & 5 & 0.046 & 3580 & 737 & 0.21 & 134 & 38 & 97 \\
\hline & & 10 & 0.037 & 3000 & 412 & 0.14 & 142 & 25 & 60 \\
\hline b) & $\mathrm{a}$ are on $\mathrm{t}$ & $\left.{ }_{4}\right)_{2} \mathrm{SO}$ & $8 \mathrm{wt} \%$ & & & & & & \\
\hline
\end{tabular}

Table 4. Purification of mouse-IgG monoclonal antibody from hybridoma culture broth using RDF medium supplemented with $5 \%$ fetal calf serum

\begin{tabular}{lcccccc}
\hline & $\begin{array}{c}\text { Total } \\
\text { protein } \\
{[\mu \mathrm{g} \text {-protein }} \\
\left./ \mathrm{cm}^{3}\right]\end{array}$ & $\begin{array}{c}\text { Total } \\
\text { activity } \\
{[\mu \mathrm{g} \text {-antibody }} \\
\left./ \mathrm{cm}^{3}\right]\end{array}$ & $\begin{array}{c}\text { Specific } \\
\text { activity } \\
{[\mathrm{g} \text {-antibody }} \\
/ \mathrm{g} \text {-protein }]\end{array}$ & $K[-]$ & $\begin{array}{c}\text { Purification } \\
\text { factor }^{\mathrm{b})} \\
{[-]}\end{array}$ & $\begin{array}{c}\text { Recovery } \\
{[\%]}\end{array}$ \\
\hline $\begin{array}{l}\text { Crude } \\
\begin{array}{l}\text { Aqueous two-phase } \\
\text { extraction }\end{array}\end{array}$ & 2540 & 97 & 0.038 & - & 1.0 & 100 \\
\hline
\end{tabular}

a) Pluronic F68: $1 \mathrm{wt} \%,\left(\mathrm{NH}_{4}\right)_{2} \mathrm{SO}_{4}: 23.8 \mathrm{wt} \%$. Volume ratio was 0.095 .

b) The data are on the top phase.

First, the mouse-IgG monoclonal antibody was purified from a hybridoma culture broth using serumfree medium (Table 1). All of the partition of the antibody to the top phase, its recovery from the top phase, purification factor and concentration factor increased with increasing $\left(\mathrm{NH}_{4}\right)_{2} \mathrm{SO}_{4}$ concentration. With 23.8 wt\% (50\% saturation) $\left(\mathrm{NH}_{4}\right)_{2} \mathrm{SO}_{4}$ and 1 wt\% Pluronic $\mathrm{F} 68$, the $K$ value was 90 , and the purification factor defined as the ratio of specific activity of the antibody to the initial one was enhanced to 1.8 with $85 \%$ recovery: the antibody was concentrated 7.6-fold from the original solution. Since $23.8 \mathrm{wt} \%\left(\mathrm{NH}_{4}\right)_{2} \mathrm{SO}_{4}$ solution causes salting-out to the antibody without Pluronic F68, the addition of the polymer may give rise to specific extraction of salting-out proteins.

Table 2 shows the results for separation of the human-IgM monoclonal antibody. In this case also, the $K$ value, recovery from the top phase and purification factor increased with $\left(\mathrm{NH}_{4}\right)_{2} \mathrm{SO}_{4}$ concentration. The greater part of the antibody was partitioned to the top phase and was recovered at lower salt concentration compared with the case of the mouse-IgG, corresponding to the easiness of $\left(\mathrm{NH}_{4}\right)_{2} \mathrm{SO}_{4}$ precipitation of the IgM. To recover most of the antibody in the top phase, however, $23.8 \mathrm{wt} \%\left(\mathrm{NH}_{4}\right)_{2} \mathrm{SO}_{4}$ was necessary, whereby the antibody was purified 1.2 -fold with $97 \%$ recovery and was concentrated more than 16-fold. A specific antibody activity of more than $90 \%$ was attained in the present separation.
From these results it can be concluded that this method is applicable for rough purification and concentration of monoclonal antibodies from hybridoma culture broths. The operation is simple and rapid, and hence the two-phase system may be used as an alternative to $\left(\mathrm{NH}_{4}\right)_{2} \mathrm{SO}_{4}$ precipitation and membrane concentration methods which require high-speed centrifugation or an expensive membrane unit.

Further separation of the monoclonal antibody from culture broths containing large amounts of contaminant proteins was examined. Table 3 shows the results for separation of the mouse-IgG from a culture broth of DF-ITES medium with added $0.5 \%$ BSA as a growth supplement, wherein $1 \mathrm{wt} \%$ Pluronic F68 and $23.8 \mathrm{wt} \%$ $\left(\mathrm{NH}_{4}\right)_{2} \mathrm{SO}_{4}$ were used for making aqueous two-phase. From the preliminary results that BSA tends to partition to the bottom phase by addition of $\mathrm{SCN}^{-}$ion (data not shown), two-phase systems with added $5 \mathrm{wt} \%$ and 10 wt\% NaSCN were also examined. Even in the absence of NaSCN, the $K$ value was 113 , and the purification factor increased 21 -fold with $98 \%$ recovery, whereby the antibody was also concentrated 21 -fold. On the other hand, the addition of $5 \% \mathrm{NaSCN}$ led to a 38 -fold increase in the purification factor without lowering of recovery. This is attributable to an increase in the partitioning of BSA to the bottom phase, since total protein in the top phase was decreased to 58\% compared with the result in the absence of $\mathrm{NaSCN}$. In the case of $10 \%$ $\mathrm{NaSCN}$ addition, however, the recovery of antibody 
activity decreased in spite of high $K$ value.

The separation of the antibody from the culture broth supplemented with $5 \%$ fetal calf serum was also examined (Table 4). Almost all antibodies were partitioned to the top phase with $85 \%$ recovery, and $38 \%$ of the recovered protein was the antibody. Thus, the antibody could be separated and concentrated with high recovery from the culture broth containing large amounts of contaminant proteins.

For the separation and concentration of monoclonal antibodies from the culture broth with added Pluronic F68 for the purpose of protecting cells and/or amplifying antibody production, the present system has the advantage of using the same polymer as a phase-forming polymer in aqueous two-phase extraction. Furthermore, the characteristic of solidification could facilitate the recovery of Pluronic F68 by varying the temperature.

\section{Conclusion}

Pluronic F68 was employed as a phase-forming polymer for aqueous two-phase extraction. Pluronic F68/ salt systems had a singular phase separation behavior unlike that in PEG/salt systems; i.e., solidification of Pluronic F68 was observed at high concentrations of the polymer and salts, and/or at moderate temperature. Pluronic F68/salt systems had a similar trend in protein-partitioning to $\mathrm{PEG} / \mathrm{salt}$ systems, but required high salt concentration to partition proteins to the top phase. It was shown that the systems could be used for the separation of monoclonal antibodies from various hybridoma culture broths, and the separation procedure provides a simple and rapid method for separation and concentration with high recovery.

\section{Acknowledgment}

The authors wish to thank Professor Takeshi Kobayashi, Dept. of Biotechnology, Nagoya University, for useful discussion.

\section{Litẹrature Cited}

1) Albertsson, P.- $\AA$.: "Partition of cell particles and macromolecules," Wiley, New York (1986).

2) Allen, R. J. L.: Biochem. J., 34, 858-865 (1940).

3) Bentley, K. P., R. M. C. Gates and K. C. Lowe: Biotechnol. Lett., 11, 111-114 (1989)

4) Handa, A., A. N. Emery and R. E. Spier: Dev. Biol. Stand., 66, 241-252 (1987)

5) Harris, P. A., G. Karlström and F. Tjerneld: Bioseparation, 2, 237 246 (1991).

6) Hasko, F., R. Vazileva and L. Halasz: Biotechnol. Bioeng., 24, 1931-1939 (1982).

7) Kamihira, M., I. Kawakubo, M. Taniguchi, S. Iijima and T. Kobayashi: J. Chem. Eng. Jpn., 21, 357-362 (1988).

8) Kilburn, D. G. and F. C. Webb: Biotechnol. Bioeng., 10, 801-814 (1968).

9) Krug, F. J., H. Bergamin Filho, E. A. G. Zagatto and S. S. Jörgensen: Analyst, 102, 503-508 (1977).

10) Kuboi, R., H. Tanaka and I. Komasawa: Kagaku Kogaku Ronbunshu, 16, 1053-1059 (1990).

11) Kuboi, R., H. Tanaka and I. Komasawa: Kagaku Kogaku Ronbunshu, 17, 67-74 (1991).

12) Murhammer, D.W. and C.F. Goochee: Biotechnol. Prog., 6, 391397 (1990).

13) Ogawa, T., M. Kamihira, H. Yoshida, S. Iijima and T. Kobayashi: J. Ferment. Biotechnol., 74, 372-378 (1992).

14) Takazawa, Y. and M. Tokashiki: Appl. Microbiol. Biotechnol., 32, 280-284 (1989).

15) Terashima, S., T. Ogawa, M. Kamihira, S. Iijima and T. Kobayashi: Seibutsu-kagaku Kaishi, 71, in press (1993).

16) Walter, H., D.E. Brooks and D. Fisher ed.: "Partitioning in aqueous two-phase systems," Academic Press, Orlando (1985). 